\title{
Business Improvement Districts in England and the (private?) governance of urban spaces
}

\author{
Dr Claudio De Magalhães \\ Bartlett School of Planning - UCL \\ Wates House \\ 22 Gordon Street \\ London WC1H 0QB \\ UK \\ c.magalhaes@ucl.ac.uk
}

Word count: 7,084 (excluding abstract, tables and references) 


\begin{abstract}
Business Improvement Districts (BIDs) were introduced in the England less than 10 years ago and their adoption in over 140 locations all over the country owns a great deal to their potential ability to raise private funds to invest in the development of business areas. However, much of the academic literature on BIDs has been crtical of what it sees as an expansion of corporate control of urban spaces and the weakening of elected local government, often on the evidence of a longrunning North American debate. On the basis of 10 case studies of English BIDs, this paper addresses the evolution of those organisation as private stakeholder-led instruments for the governance and management of business areas in England. The papers discusses whether and to what extent English BIDs constitute private government of urban areas, and the attendant issues of accountability and spatial inequalities in the distribution of public services and investment. It concludes by examining the the implications of its findings for the future of urban governance.
\end{abstract}

Keywords: Business Improvement Districts, urban governance, stakeholder-led governance, privatisation, private service delivery, BIDs accountability 


\section{BIDs and public realm governance: the issues}

Over the last two decades, there has been a noticeable emergence in the UK of forms of public realm management that do not conform to an established division of roles, in which the state is the provider of services and both the market and civil society are the recipients of those services. The rationale driving this process has been linked to approaches to urban governance that advocate a reduced role for the state and the transfer of responsibilities to stakeholders outside the public sector, and emphasise partnerships and collaboration in the provision of public goods and services, (Leach and Percy-Smith 2001, Sullivan and Skelcher 2002). The recent emergence of the 'Big Society' and Localism agendas in the UK has given an added impetus to this drive towards alternative forms of service provision and governance, with their focus on the neighbourhood and the promotion of an increasing role for civil society in managing its own affairs (CLG 2010, Bailey and Pill 2011).

Whether or not the multiplication of those 'collaborative' forms of public realm management is to be desired, they are now widespread, and Business Improvement Districts (BIDs) are perhaps their more structured form. A policy import from North America, they were regulated in England in 2004 with the first BIDs coming to existence at the end of that year. In their English incarnation, they are in essence a partnership of occupiers of commercial property with their local authority, with powers to decide on a compulsory surtax, ring-fenced to pay for additional services and improvements in their locality. In the 8 years since the passing of the first regulations enabling BIDs, more than 140 have been created (British BIDs 2012). At the end of 2010, when the data for this paper was

collected, that total stood at 100 (Figure 1), with success in 5 out of 6 BID proposals. About a third of them have already succeeded in obtaining a second 5-year mandate, with only six recorded cases of unsuccessful renewal vote so far (British BIDs 2012). 


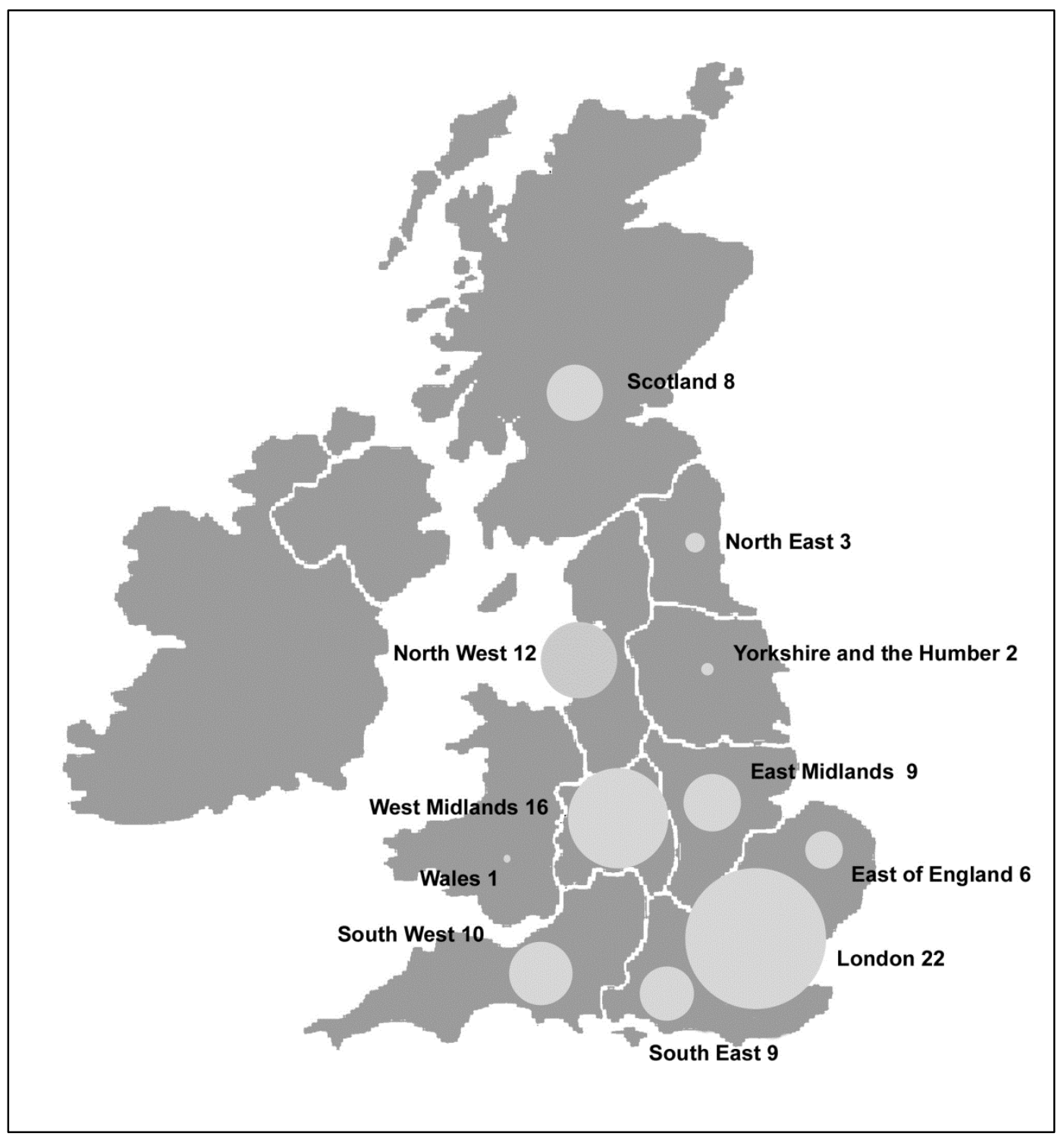

Figure 1: BIDs in operation in the UK: BIDs per region (November 2010 - Source UKBIDs)

However, the apparent success of BIDs as suggested by rapidly increasing numbers should not obfuscate the complex and contentious issues that are associated with them. A quick glance at the relevant literature in the last few years suggests a spectrum of conflictive views. Much of the discussion has a strong ideological underpinning and both advocates and detractors have made their cases drawing on different aspects of a mostly North American evidentiary base (see Briffault 1999 and Morçöl et al 2008 for summaries of the debate and the evidence). 
On one end, BIDs have been see primarily as a mechanism for tacking the decline of city centres and the inefficiencies of local government and improving city services without further recourse to public funds (Baer and Feiock 2005, Hoyt and Gopal-Agge 2007, Justice and Goldsmith 2006). On the other, BIDs have been linked to the deployment of private wealth and power to gain control over the public realm to deliver a privatist and privatising agenda (Low and Smith 2006, Minton 2009, Ward 2006, Mitchell and Staeheli 2006).

Three issues emerge from the debate about the character of BIDs as public realm governance instruments (see Hoyt and Gopal-Agge 2007, Briffault 1999). The first refers to whether or to what extent BIDs represent the privatisation of the governance of public spaces. In its most critical, this concern associates BIDs with the de-legitimisation of elected local government, the privileging of commercial interests and de-enfranchising of residents and others, together with a narrower definition of entitlement to public space (Low and Smith 2006, Schaller and Modan 2009, Kohn 2004).

This depiction of BIDS as having a primarily narrow-interest, private-government, character has nonetheless been contested, not the least by calling attention to the considerable role of public sector in creating, empowering and controlling them (Briffault 1999, Steel and Symes 2005). The public-private partnership character of BIDs has been emphasised, together with the strong and complex legal framework separating governance arrangements for a private a mall from those for public streets (Steel and Symes 2005). Moreover, the uniqueness or newness of BIDs as instruments of a private sector-dominated local government might have been overstated, given the long tradition of private involvement in local government in the US (Briffault 1999, Mallet 1994).

In the UK, BIDs have been created in a context characterised by what Ward (2006) describes as 'centrally prescribed localism', with a much stronger role of national government in shaping changes in the nature of local government and the powers of alternative governance instruments. Their public-private partnership character has been more evident, in line with a tradition of such 
partnerships in urban policy delivery (Steel and Symes 2005, Lloyd et al 2003, Peel et al. 2009). Therefore, although conceived as business-led entities, UK BIDs belong to a tradition of publicprivate partnerships in area governance which rely on the private sector for its presumably more efficient modus operandi, but do not dispense with the statutory powers and responsibilities of the public sector (Lloyd and Peel 2008). For those partnerships, the legal, political and material support from statutory public sector bodies is a condition for success, as are public sector grants for capital investment. Nevertheless, this partnership character is not itself a guarantee that private interests will not dominate, and the history of public-private partnerships in the UK provides several examples on that regard (see Foley and Martin 2000, Deakin 2002, Imrie and Thomas 1999)

Following from the above, the second main concern relates to democratic accountability in decisions involving the public realm. BIDs are directly accountable to those businesses that make them up. Non-participant businesses, residents and the population at large do not normally have a direct say on BIDs' decisions, although they might have a legitimate interest in their impact on their locality. In the US, this issue has been formulated as a violation of the one-person-one-vote principle in urban governance and a challenge to democratic polity as it establishes the principle of political influence proportional to value of property (Kohn 2004). However, it should be noted that legal challenges to BIDs on that basis have been defeated in US courts (Briffault 1999). In the UK, the more prominent powers given to local authorities in the creation and operation of BIDs make the lines of accountability of BID decisions to elected government more visible. However, the concern remains that as representatives of specific business interests, BIDs could create clean and safe places for particular kinds of people and not others (Minton 2009), or bring about potential homogenisation of cities favouring particular forms of work, consumption and leisure, to the detriment of others (Steel and Symes 2005).

A third concern refers to the potential exacerbation of inter-local inequalities in the provision of public services, as the ability to pay becomes a determinant in the quantity and quality of those services (Kohn 2004, Baer and Feiock 2005). Critics see a risk of BID areas becoming communities 
of like-incomes, becoming a separate city within the city (Minton 2009). This concern has taken a more acute form in the US, with the suggestion of the reproduction within cities of a pattern of considerable public service inequality and governance balkanisation that is all too prevalent among municipalities within metropolitan areas (Briffault 1999). The same concern with potential public service inequalities has been raised in the UK (Minton 2009; Lloyd et al 2003). However, this has to be put in the context of a tradition of area-based urban regeneration initiatives, predicated on the spatial differentiation of public investment as a tool to attract private investment to specific areas. Moreover, BIDs' investment in public services, no matter how large, would still be a tiny fraction of the total amount of public sector spending on public services on any areas, if the full remit of such services is taken into account (Briffault 1999). The real question therefore is whether the resulting inequality is of significance in its impact on the quality of life of different sectors of the urban population, and whether it has the potential to be deleterious to public policy aims for the BID area and the towns and cities where they are located.

These three concerns are not new: Hoyt and Gopal-Agge (2007) discuss a similar set of issues from a North American point of view, and they inform the assessment of the democratic performance of BIDs by Justice and Skelcher (2009). However, the particularities of British BIDs ask for a more contextualised treatment. This paper looks at the three issues of privatisation of government, accountability and spatial inequality in service provision in the context of English BIDs, and tries to understand whether these are real issues or to what extent they are so.

The next section gives an overview of the explanations for the emergence of BIDs as a form of public realm management and explains the particular form BIDs have assumed in the UK. This is followed by an examination of the empirical evidence for 10 case studies, looking in turn at the proposition of BIDs as private government, the nature of their accountability mechanisms and their impact as area-focused service providers. A concluding section summarises the findings and looks at their more general implications. 


\section{The context: public realm management failures and the British BID model}

The history of BIDs as instruments of urban management in North America is well documented (see Morçöl et al 2008), as is the process of policy import that brought BIDs to the UK (see Ward 2006). Two main factors characterise the context for that import. Firstly, continuous policy efforts at national level to reduce the costs and size of government have resulted in the curbing of powers and spending of local authorities and a redistribution of resources within public services (Leach and Percy-Smith 2001,). They have also led to the flowing of power to a plethora of subsidiary bodies within and outside the formal boundaries of the state (Rhodes 1997), thus giving rise to the need for forms of collaboration between different sectors and jurisdictions for the delivery of public goods and services (Goss 2001, Sullivan and Skelcher 2002).

Secondly, the perceived need for British cities to compete to attract the more footloose investment of the globalised economy led to an increasing concern with the vitality and viability of town and city centres and the role in this of public realm quality (see e.g. Urban Task Force 1999; DETR 2000). This was happening at a time when changes in the nature of retail were exacerbating competition between locations, pitching traditional town centres against new retail formats in outof-town locations, with profound implications for those operating business and owning property in central areas, as well as those depending on them to meet their needs (Urban Task Force 1999).

In a policy environment dominated by an emphasis on entrepreneurialism, the effective response to those problems was thought to be beyond the ability of traditional state funded, local authoritybased public realm management systems (ODPM 2004a, De Magalhães and Carmona 2006). In such a context, the introduction of BIDs in the Local Government Act 2003 was a further development of the same approach that led to the creation of Town Centre Management partnerships. These were the voluntary public-private arrangements for the management of town centres of variable degree of formality that had been the initial response to perceived management failure and lack of competitiveness of town centres (Peel et al 2009, Reeve 2008). 
The 2004 regulations (Statutory Instrument 2004 No. 2443) set out in detail how BIDs should take shape in the England (similar legislation was passed for Wales in 2005 and Scotland in 2006). They determine a consultation process before a BID is set up, culminating in a vote, in which all potential levy payers should decide by a majority (of voters and rateable value) whether to approve the BID proposal. The regulations give local authorities the role of overseeing the BID formation process, which includes the right to veto BID proposals under specified circumstances (UK Parliament 2004).

The BID proposal is formalised in a Business Plan that sets out the value of the levy, who is liable to pay it and who is not (particular types of businesses or those below a certain threshold of rateable value might be exempted), how it will be spend and how the BID will be managed (ALG, 2005). Once approved, that Plan is a legally binding document, tying the BID to the delivery of a set of outputs. These normally include 'clean, green and safe' services such as CCTV, street cleansing and place-marketing initiatives. Baseline agreements signed with the local authority and other service providers detail the level of services the BID should expect from them. In theory, these agreements should ensure that BID intervention is additional to regular public service provision and not a replacement for it.

Once approved, the BID is constituted into a legal entity, normally a not-for-profit company with a management board composed primarily of levy-paying businesses and directed by them, but often including representatives of the local authority, and occasionally residents and representatives of other important local stakeholders with various degrees of voting rights.

The main statutory source of funds for the BID is the levy, a compulsory surtax collected by the local authority and deposited in a special account, to be spent in the proposals outlined in the Business Plan. The levy is normally but not necessarily calculated as a specific percentage of the rateable value for which participating businesses are liable. For the vast majority of BIDs the levy has been set around a figure of between $1 \%$ and $2 \%$ of the rateable value of each business (British BIDs 2012), although some BIDs have opted for flat fees, banding or graded levies. 
It is in the nature of those funding arrangements that BIDs in the UK differs significantly from those in the US and elsewhere, where the levy is charged against property owners rather than occupiers of commercial property. The explanation for this peculiar British solution to BID funding comes from the Government's decision to define the levy as a surcharge on non-domestic property rates. Usually referred to as business rates, they are a tax on the occupation of commercial properties rather than a tax on the ownership of those properties. There was considerable discussion preceding the approval of the 2003 Act and the 2004 Regulations about the merits of defining the BID levy as a surcharge on the occupier-paid business rates, but the expediency of relying on a well-establish taxation mechanism won the argument (see e.g. Blackwell 2005, ODPM 2004b).

Business rates were originally a local tax to pay for local public services but since 1988, they have been collected by the national government with the proceeds transferred to local authority according to a distributive formula. The incidence of the tax on any particular property is calculated as a function of nationally ascribed rental values for units of property (hereditaments) of similar characteristics, which are submitted to revaluation at periods of around 5 years or in the event of significant improvements to the property. Given that most businesses in British town centres and commercial areas rent their premises, the option for an occupation tax as the basis for the levy has meant that property owners for the most part are not levy payers and do not have any part in the setup and governance of BIDs, despite their obvious stake in them.

The choice of an occupier-based levy has also had direct implications for amount of income that can be raised, a function of the typical range, size and turnover of business occupiers in town and city centres and industrial areas around the country. Evidence suggests this amount is less than what would be raised by property owner-based levies (Blackwell 2008, CLG 2007). As an example, the largest British BID by far, the New West End Company in London expected an income in 2010 of just under $£ 5$ million - three times more than the second richest BID - of which just $50 \%$ was income from the levy and at least $20 \%$ were public sector transfers (NWEC 2008). This can be compared with large property-owner funded New York BIDs such as Times Square and Grand 
Central, with incomes for the same year of circa $£ 10$ million, 65\% of which from the levy, supported by asset bases valued at $£ 3$ million and $£ 15$ million respectively (TSDMA 2010, GCP \& GCDMA 2010). The average annual income of BIDs in Britain at around $£ 400,000$ is far lower than those values, with many small BIDs raising even smaller amounts (British BIDs 2012). To make up for this, the model encourages the topping up of levy income with grants from public sector programmes, voluntary contributions from property owners, private and public sponsorship and contributions in kind from local authorities and others.

All those particularities of in the constitution and operation of British BIDs are fundamental in framing the discussion about their nature as governance instruments. This is discussed in the next section.

\section{English BIDs: the empirical evidence}

This section examines the issues of private governance, accountability and unequal provision of services based on evidence provided by 10 case studies of BIDs in England. The location of the cases is presented in Figure 2, and basic information about each case is shown in Table 1. The cases try to encompass the diversity of sizes, income, locations and economic backgrounds that characterises the universe of English BIDs:

- Three cases of metropolitan core BIDs, differentiating between London and other major English cities and according to the nature of dominant businesses (offices, retail, leisure)

- One large metropolitan periphery BID in London, in a complex competitioncomplementarity relationship with core metropolitan locations and other suburban centres

- Four cases of free-standing town centre BIDs, with a variety of backgrounds (degree of regional prosperity, threat from competing centres, size and income) 
- Two cases of industrial BIDs, differentiating according to size, spatial dispersal/ compactness and type of uses

The selection of the cases was informed by a survey of the circa 100 BIDs in operation in late 2010/early 2011, which provided a general overview of universe of BIDs in England and confirmed the potential usefulness of the categorisation of BIDs by their locational context (see RICS 2011). BID managers and local authority officials were interviewed in each of the ten locations. The interviews explored the main motives for the formation of the BID, the nature of its agenda and how it has sought to deliver that agenda; its sources of income for and how this income has been distributed among agenda items; the nature of the services provided by the BID; the strategies each of the cases has adopted to consolidate their role in the governance of their location; the challenges and threats facing each BID individually and the BID model as a whole, together with the main opportunities for growth and consolidation. Interview data was complemented by secondary information from approved business plans and annual accounts publicly available from the BIDs' websites. 


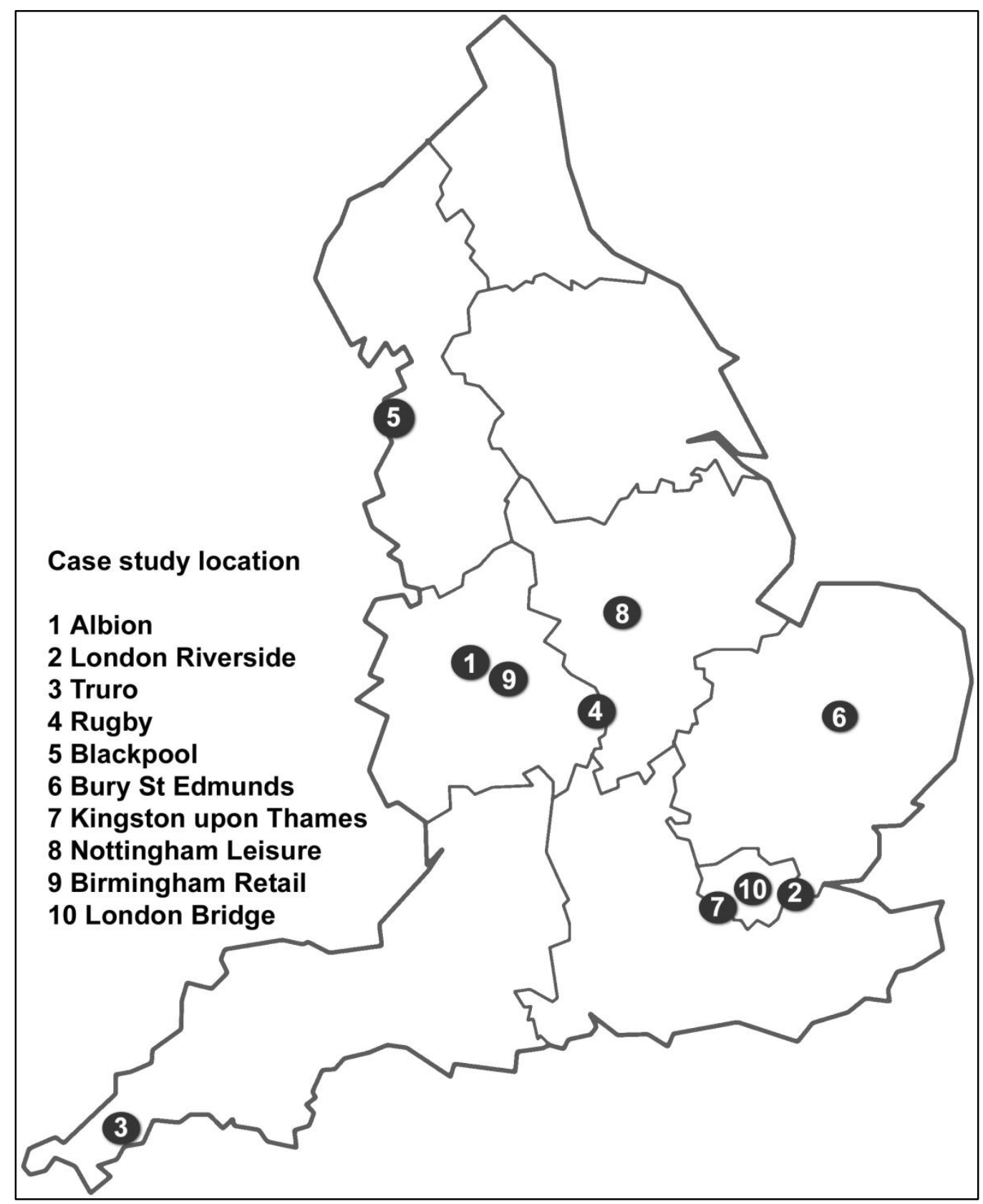

Figure 2: Location of case studies in England 
Table 1: The case studies: basic information

\begin{tabular}{|c|c|c|c|c|c|c|c|c|c|c|}
\hline BID Name & $\begin{array}{l}\text { London } \\
\text { Bridge }\end{array}$ & $\begin{array}{l}\text { Birmingham } \\
\text { Retail }\end{array}$ & $\begin{array}{l}\text { Nottingham } \\
\text { Leisure }\end{array}$ & Kingston & Blackpool & Rugby & Truro & $\begin{array}{l}\text { Bury St } \\
\text { Edmunds }\end{array}$ & $\begin{array}{l}\text { London } \\
\text { Riverside }\end{array}$ & Albion \\
\hline Type of BID & $\begin{array}{l}\text { Office } \\
\text { dominated } \\
\text { BID, Central } \\
\text { London }\end{array}$ & $\begin{array}{l}\text { Retail core of } \\
\text { Birmingham, } \\
\text { retail } \\
\text { businesses } \\
\text { only }\end{array}$ & $\begin{array}{l}\text { Central } \\
\text { Nottingham, } \\
\text { alcohol- } \\
\text { licensed } \\
\text { businesses } \\
\text { only }\end{array}$ & $\begin{array}{l}\text { Large Outer } \\
\text { London } \\
\text { town centre } \\
\text { BID, all } \\
\text { types and } \\
\text { sizes of } \\
\text { businesses }\end{array}$ & $\begin{array}{l}\text { Free- } \\
\text { standing } \\
\text { town centre } \\
\text { BID in the } \\
\text { North West, } \\
\text { with many } \\
\text { small } \\
\text { businesses }\end{array}$ & $\begin{array}{l}\text { Free- } \\
\text { standing } \\
\text { town centre } \\
\text { BID in the } \\
\text { West } \\
\text { Midlands } \\
\text { with many } \\
\text { small } \\
\text { businesses }\end{array}$ & $\begin{array}{l}\text { Free- } \\
\text { standing } \\
\text { town centre } \\
\text { BID in } \\
\text { Cornwall, } \\
\text { with many } \\
\text { small } \\
\text { businesses }\end{array}$ & $\begin{array}{l}\text { Free-standing } \\
\text { town centre } \\
\text { BID in the } \\
\text { East of } \\
\text { England, } \\
\text { many small } \\
\text { businesses }\end{array}$ & $\begin{array}{l}\text { Large } \\
\text { industrial area } \\
\text { BID, several } \\
\text { industrial } \\
\text { estates with } \\
\text { business of } \\
\text { varied size }\end{array}$ & $\begin{array}{l}\text { Compact } \\
\text { industrial area } \\
\text { BID, adjacent } \\
\text { industrial } \\
\text { estates with } \\
\text { metal-related } \\
\text { industries }\end{array}$ \\
\hline $\begin{array}{l}\text { Size (No. of } \\
\text { hereditaments) }\end{array}$ & 400 & 420 & 266 & 900 & 800 & 460 & 400 & 380 & 250 & 123 \\
\hline $\begin{array}{l}\text { Regular } \\
\text { annual income } \\
(\mathbf{2 0 1 1})\end{array}$ & $£ 1,000,000$ & $£ 1,200,000$ & $£ 370,000$ & $£ 1,100,000$ & $£ 400,000$ & $£ 850,000$ & $£ 290,000$ & $£ 330,000$ & $£ 140,000$ & $£ 170,000$ \\
\hline $\begin{array}{l}\text { Business Plan } \\
\text { expenditure } \\
\text { composition }\end{array}$ & $\begin{array}{l}\text { Safe/Secure } \\
\text { (inc. } \\
\text { Cleaning) } \\
22 \% \\
\text { Marketing } \\
\text { /Events 22\% } \\
\text { Environment } \\
\text { / Community } \\
22 \% \\
\text { Other (inc. } \\
\text { business } \\
\text { support) 8\% } \\
\text { Management } \\
\text { Costs 26\% }\end{array}$ & $\begin{array}{l}\text { Safe/Secure } \\
\text { (inc. } \\
\text { Cleaning) } \\
30 \% \\
\text { Marketing } \\
\text { /Events 50\% } \\
\text { Other (inc. } \\
\text { business } \\
\text { support) } 8 \% \\
\text { Management } \\
\text { Costs 12\% }\end{array}$ & $\begin{array}{l}\text { Safe/Secure } \\
24 \% \\
\text { Marketing } \\
\text { /Events 40\% } \\
\text { Business } \\
\text { Support 13\% } \\
\text { Management } \\
\text { Costs 23\% }\end{array}$ & $\begin{array}{l}\text { Safe/Secure } \\
8 \% \\
\text { Marketing } \\
\text { /Events 30\% } \\
\text { Cleaning } \\
30 \% \\
\text { Street } \\
\text { Markets } \\
\text { Management } \\
\text { (contract } \\
\text { from local } \\
\text { council) 10\% } \\
\text { Other 2\% } \\
\text { Management } \\
\text { Costs 20\% }\end{array}$ & $\begin{array}{l}\text { Safe/Secure } \\
13 \% \\
\text { Marketing } \\
\text { /Events 45\% } \\
\text { Cleaning } \\
15 \% \\
\text { Business } \\
\text { support 3\% } \\
\text { Managemen } \\
\text { t Costs 24\% }\end{array}$ & $\begin{array}{l}\text { Safe/Secure } \\
\text { inc. CCTV } \\
55 \% \\
\text { Marketing } \\
\text { /Events } 10 \% \\
\text { Cleaning } \\
10 \% \\
\text { Management } \\
\text { Costs 25\% }\end{array}$ & $\begin{array}{l}\text { Marketing } \\
\text { /Events 65\% } \\
\text { Other 5\% } \\
\text { Management } \\
\text { Costs 30\% }\end{array}$ & $\begin{array}{l}\text { Safe/Secure } \\
33 \% \\
\text { Marketing } \\
\text { /Events 65\% } \\
\text { Cleaning 2\% } \\
\text { management } \\
\text { Costs not } \\
\text { budgeted (paid } \\
\text { by local } \\
\text { council) }\end{array}$ & $\begin{array}{l}\text { Safe/Secure } \\
\text { inc. CCTV } \\
42 \% \\
\text { Marketing } \\
\text { /Events 7\% } \\
\text { Cleaning 26\% } \\
\text { Management } \\
\text { Costs 25\% }\end{array}$ & $\begin{array}{l}\text { Safe/Secure } \\
\text { inc. CCTV } \\
60 \% \\
\text { Marketing } \\
\text { /Events 15\% } \\
\text { Management } \\
\text { Costs 15\% }\end{array}$ \\
\hline
\end{tabular}

Source: BID Business Plans, adjusted by interview data 


\subsection{BIDs as private government of town centres and industrial areas?}

BIDs embody a transfer of governance powers from local government to a business-led entity, and even if these are not general powers over the BID area, they are powers to make decisions about, and deliver services and improvements in that area, according to an agenda set out by those businesses with voting rights. This might not constitute a replacement of local government with a private, business-led government, but it does represent an assertion of business interests and private rights over parts of the public realm. The issue therefore is not an outright opposition between a local authority-led and a private-led government of the public realm. It is instead whether the relatively limited transfer of governance powers to BIDs is enough to undermine the legitimacy of elected government and result in the appropriation of the public realm by corporate interests. Given that BIDs are in essence service delivery organisations, that issue can be formulated in terms of the nature of the services they perform, and how those services relate to those delivered by the local authority. Is their scope wide enough to characterise a significant degree of control over the public realm? Do these services configure a governance agenda that is separate from, and conflictive with, that of the local authority?

The ten BIDs examined in this research deliver a variety of services, but these are concentrated in two headings: 'safe and secure' (CCTV operation; radio links between businesses, the BID and the police; street wardens/rangers; taxi marshals; etc.), and marketing and events (festivals, festive lights, loyalty schemes, publicity, etc.) (see Table 1). If management costs are discounted, 'safe and secure' and 'marketing and events' respond for between $60 \%$ and $90 \%$ of expenditure. Additional street cleaning is delivered by most BIDs, but the service is only significant in itself in a few of the cases. A few BIDs offer some sort of business support service, from joint procurement of e.g. waste recycling to networking opportunities, but this remains mostly incipient.

The emphasis on marketing and safety is reflected in the key objectives of the ten BIDs and in nature of the main projects in which they are involved (Table 2). Some BIDs were created to tackle the commercial decline of town centres, others the real or perceived problems of safety, others still 
to make the most of development or regeneration projects or to secure funding for particular events or initiatives regarded as essential to the economic success of their localities. In nearly all the cases the key objectives of each BID derive from agendas established in previous partnership vehicles involving local businesses and the local authority (Table 2). This suggests a process of continuity, in which BIDs often constitute the latest institutional step to deliver an agenda of local improvements and services matured through several interactions between businesses and between them and the local authorities and other public sector agencies. It also suggests some form of coordination and complementarity between the projects and services delivered by the BIDs and those delivered by public sector providers.

Table 3 shows the services provided by the ten cases. Many are an extension of existing local authority-funded services (e.g. addition to existing marketing initiatives, extension of street rangers service, more police patrols, more street cleaning rounds, extended CCTV monitoring). Others ensure the coordination of separate but related public services (e.g. coordination of homeless services, or crime-prevention radio links), or make viable services that had not been fully explored because of shortage of funding (e.g. particular marketing events, taxi marshals, quick-response litter and graffiti removal, road signage). Although the services are varied, there is little to suggest that they signify a substantial degree of control over the management of the public realm. The key public realm management functions of coordinating public realm interventions, regulating uses and activities, funding capital projects and of determining and delivering most maintenance routines are still firmly in the hands of local authorities.

The functional connections between BIDs and local authorities would indicate a complementarity of agendas, in which the business-led aspirations represented by a BID are to a large degree absorbed within, and framed by, those of elected local government. In this context, those BIDs are to a large degree the delivery instruments of an agenda for the regeneration and economic development of town centres and industrial areas generated by a governance nexus of local businesses, local and national government and other public agencies, in a complex and increasingly fragmented and 
'devolved' governance landscape. This would explain the investment many local authorities have made in the creation of BIDs and their on-going support for them, political as well as material, as indicted by the generalised occurrence of in-kind contributions to running and management costs. That support goes from advance transfer of levy revenues, to support for projects, to staffing and premises, levy collection and other costs, and can be a significant proportion of the resources available to smaller BIDs (see De Magalhães 2012).

Overall, therefore, the evidence from the study is that BIDs have not come to constitute a relatively autonomous agent of public realm governance and management, independent of, and in conflict with, the elected local authority. Their autonomy to shape the public realm in the image of business interest has been limited by both the amount of resources they can raise and the nature of their relationship with local government. Those limits mean that for the most part, what BIDs effectively do is to coordinate, complement and extend services and activities already in place. This is so even as regards safety and security, an area of BID activity that has been particularly scrutinised in the academic literature - and the findings here mirror those of Vindevogel (2005) for a sample of US BIDs. Rather than privatised government of the public realm, English BIDs appear as a hybrid of private club and public agency (see Justice and Skelcher 2009), operating within a network of organisations centred in the local authority, and connected to one another through a mix of legal and contractual relationships of the sort described by Peel et al. (2009).

The extent to which that network is adequate to prevent what Madanipour (2003) defines as smallgroup control of the public realm is the real issue, and the nature of its accountability mechanisms provides a large part of the answer. This is discussed in the next section. 
Table 2: BIDs' key objectives and projects

\begin{tabular}{|c|c|c|c|}
\hline BID & Origins & Key objectives & Key projects \\
\hline London Bridge & $\begin{array}{l}\text { SRB urban regeneration project involving } 2 \\
\text { local authorities }\end{array}$ & $\begin{array}{l}\text { Improve the image of the office district and } \\
\text { reduce the impact of large developments }\end{array}$ & $\begin{array}{l}\text { Marketing events, environment and community } \\
\text { projects }\end{array}$ \\
\hline Birmingham Retail & $\begin{array}{l}\text { Evolution of council's City Centre Management } \\
\text { Team and City Centre Partnership }\end{array}$ & Manage the retail environment in city centre & Marketing events \\
\hline Nottingham Leisure & Council strategy for city centre & $\begin{array}{l}\text { Manage the night-time economy and prevent } \\
\text { anti-social behaviour }\end{array}$ & Taxi Marshals, marketing events \\
\hline Kingston & $\begin{array}{l}\text { Evolution of successful Town Centre } \\
\text { Management company }\end{array}$ & Secure the vitality of town centre & Marketing events \\
\hline Blackpool & $\begin{array}{l}\text { Evolution of council-backed Town Centre } \\
\text { Forum, to capitalise on urban regeneration } \\
\text { investment }\end{array}$ & $\begin{array}{l}\text { Prevent the decline of the town centre and } \\
\text { increase safety }\end{array}$ & Marketing events and Wardens \\
\hline Rugby & $\begin{array}{l}\text { Evolution of council-led Town Centre } \\
\text { Management company }\end{array}$ & Prevent anti-social behaviour in town centre & CCTV operation and Street Rangers \\
\hline Truro & $\begin{array}{l}\text { Economic development strategy led by } \\
\text { district council }\end{array}$ & $\begin{array}{l}\text { Convert visitor and commuter flux into } \\
\text { custom for town centre }\end{array}$ & Christmas lights \\
\hline Bury St Edmunds & $\begin{array}{l}\text { Council's strategy to formalise Town Centre } \\
\text { Management partnership }\end{array}$ & Town centre management & Street Rangers and Christmas Lights \\
\hline London Riverside & $\begin{array}{l}\text { Evolved from business-led economic } \\
\text { development partnership, supported by the } \\
\text { council and Regional Development Agency }\end{array}$ & Crime prevention & CCTV system \\
\hline Albion & $\begin{array}{l}\text { Created as exit strategy for government- } \\
\text { funded urban regeneration programme NDC } \\
\text { to succeed previous partnership }\end{array}$ & Crime prevention & CCTV system \\
\hline
\end{tabular}

Source: BID proposals, business plans and interview data 
Table 3: Nature of BID services

\begin{tabular}{|c|c|}
\hline Cases & Main Services (nature and scope) \\
\hline London Bridge & $\begin{array}{ll}\text { - } & \text { Safety/Street Scene (additional policing and street cleansing/lighting) (31\% of spend) } \\
\text { - } & \text { Place Promotion (marketing/events) ( } 31 \% \text { of spend) } \\
\text { - } & \text { Responsible Business (environmental and community projects) (31\% of spend) }\end{array}$ \\
\hline $\begin{array}{l}\text { Retail } \\
\text { Birmingham }\end{array}$ & 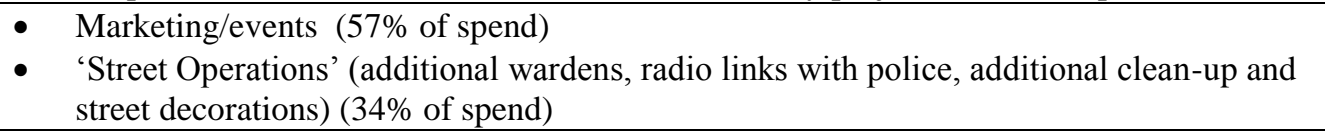 \\
\hline $\begin{array}{l}\text { Nottingham } \\
\text { Leisure }\end{array}$ & 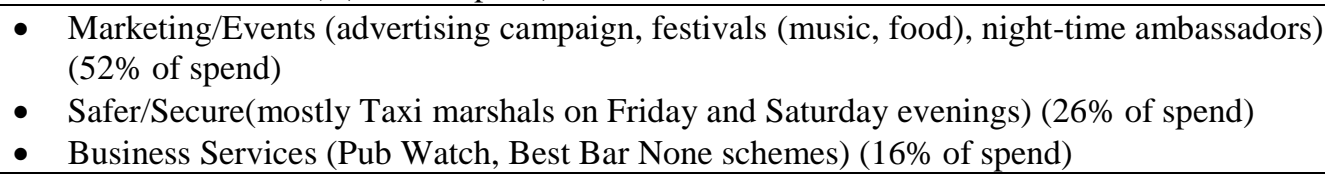 \\
\hline $\begin{array}{l}\text { Kingston upon } \\
\text { Thames }\end{array}$ & 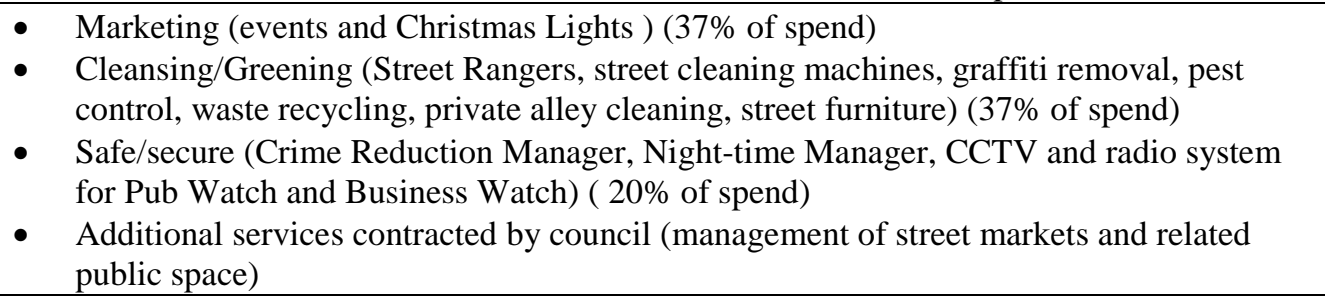 \\
\hline Blackpool & $\begin{array}{l}\text { - } \\
\text { - } \\
\text { - }\end{array}$ \\
\hline Rugby & 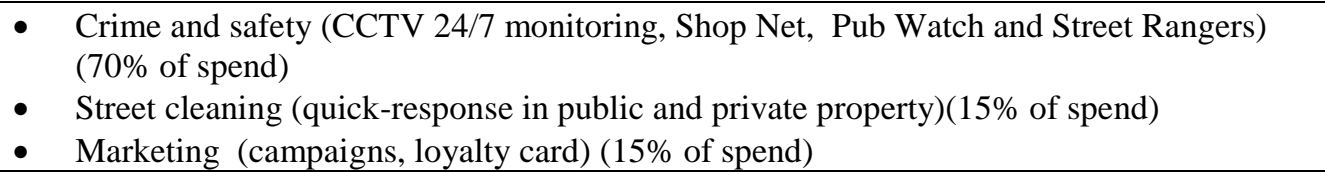 \\
\hline Truro & $\begin{array}{l}\text { - Marketing and Events (Christmas Lights Autumn music and Spring arts festivals, } \\
\text { marketing campaigns) ( } 93 \% \text { of spend) } \\
\text { - Shop mobility ( } 5 \% \text { of spend) } \\
\text { - Joint management of public spaces with the city council }\end{array}$ \\
\hline $\begin{array}{l}\text { Bury St } \\
\text { Edmunds }\end{array}$ & $\begin{array}{ll} & \text { Marketing and events (Christmas lights and events) ( } 65 \% \text { of spend) } \\
\text { - } & \text { Safe and security (Street Rangers) (33\% of spend) }\end{array}$ \\
\hline $\begin{array}{l}\text { London } \\
\text { Riverside }\end{array}$ & $\begin{array}{l}\text { - Safe and secure ( CCTV } 24 / 7 \text { operation, night-time/weekends mobile patrols, radio } \\
\text { service) (56\% of spend) } \\
\text { - Clean (litter patrols and removal of fly-tipping on private roads) }(35 \% \text {, of spend) } \\
\text { - 'Coordination' (promotion and lobbying) (9\% of spend) }\end{array}$ \\
\hline Albion & $\begin{array}{l}\text { - } \quad \text { Safer/Secure (CCTV operation and equipment and mobile patrols) (70\% of spend) } \\
\text { - } \quad \text { Marketing (events, campaigns and business advice) (18\% of spend) } \\
\text { - } \quad \text { 'Better Place' (banners and cleanup) ( } 12 \% \text { of spend })\end{array}$ \\
\hline
\end{tabular}

Source: BIDs Business Plans and interview data 


\subsection{BIDs and accountability: to whom and how?}

BID are a partnership for raising and managing a surtax to fund public realm improvements in a defined locality, and they embody the principle that those who undertake to pay that surtax should have the power to decide on how it is spent. Not surprisingly, the 2004 regulations put considerable emphasis in the mechanisms that could make BIDs proposals and decisions directly answerable to levy-payers and ensure their control over the day-to-day running of BIDs. In the same vein, the regulations provide a sunset clause it the BID fails to meet the expectations of levy-payers.

This understanding of accountability is reflected the decision-making structures of all 10 cases, shown in Table 4. It is clear that decision-making power rests with levy-paying business, although local authorities are part of most BID boards. In some of the cases, other stakeholders have a formal role, from advisory to full voting rights.

Table 4: BIDs' decision-making structures and stakeholder involvement

\begin{tabular}{|c|c|}
\hline Cases & BID Board membership and advisory bodies \\
\hline London Bridge & $\begin{array}{l}\text { - } 8 \text { members representing levy payers, property owners and } 1 \text { councillor } \\
\text { - } \quad \text { Advisory property owners forum }\end{array}$ \\
\hline $\begin{array}{l}\text { Retail } \\
\text { Birmingham }\end{array}$ & $\begin{array}{l}\text { - } 17 \text { members, } 13 \text { representing different sectors of levy payers, the large shopping centres, } \\
\text { property owners, and } 4 \text { representing the police, city centre residents and } 2 \text { councillors } \\
\text { - Advisory City Centre Neighbourhood Forum (residents) }\end{array}$ \\
\hline $\begin{array}{l}\text { Nottingham } \\
\text { Leisure }\end{array}$ & - 14 members Board representing levy payers and including 1 councillor \\
\hline $\begin{array}{l}\text { Kingston upon } \\
\text { Thames }\end{array}$ & $\begin{array}{l}\text { - } 22 \text { members representing levy payers, property owners, education establishments and } \\
\text { including } 2 \text { councillors } \\
\text { - Advisory Management Group (voluntary sector, residents, special interest groups, business, } \\
\text { the council and emergency services) }\end{array}$ \\
\hline Blackpool & - 12 members representing levy payers with 2 councillors and 1 for the police \\
\hline Rugby & $\begin{array}{l}\text { - } 20 \text { members, with } 14 \text { representing levy payers, } 2 \text { executive directors, Warwickshire } \\
\text { Chamber of Commerce and } 3 \text { from the borough and County Councils) }\end{array}$ \\
\hline Truro & $\begin{array}{l}\text { - } 14 \text { members, with } 11 \text { representing levy payers, Truro City council Town Clerk and } 2 \\
\text { Cornwall Council councillors }\end{array}$ \\
\hline $\begin{array}{l}\text { Bury St } \\
\text { Edmunds }\end{array}$ & - 11 members representing levy payers, 1 councillor and 1 council officer \\
\hline $\begin{array}{l}\text { London } \\
\text { Riverside }\end{array}$ & $\begin{array}{l}\text { - } 5 \text { members (businesses) and a steering group of } 12 \text { representing the different industrial } \\
\text { estates within the BID. } 1 \text { councillor as observer }\end{array}$ \\
\hline Albion & $\begin{array}{l}\text { - } 10 \text { members representing levy payers and } 4 \text { observers from the police, the council, property } \\
\text { owners and other business interests }\end{array}$ \\
\hline
\end{tabular}

Source: BID Proposals and Business Plans 
However, levy-paying businesses are not the only players with legitimate interests in commercial areas. Issues of accountability arise from the way the interests of non-levy paying businesses, residents or users of commercial areas might be affected by BID decisions. In the British BID model, bringing together the diffuse multiplicity of often-conflictive aspirations for those areas and securing acceptable compromises between them has remained a duty of the local authority. The key accountability issue is therefore the adequacy of the mechanisms that can bring together the specific interests of BID members expressed through and acted upon by the BID Board, with those of other stakeholders indirectly represented by the local authority. In other words, the issue is whether the difference between the direct accountability of BIDs to levy-payers and its indirect accountability to other interests via the local authority puts the latter systematically at a disadvantage. This is a difficult question to answer, precisely because of the diffuse nature of the many interests vested in the local authority.

The assumption informing the introduction of BIDs was that mobilising the stake local businesses have in their surroundings was paramount in improving the economic competitiveness of towns and city centres (DETR 2000, DTLR 2001). The corollary of that assumption was that those sectional interests and aspirations would need to operate within a government-controlled framework, to ensure that local, regional and national policy objectives are pursued. A similar rationale has informed the operation of public-private partnerships in urban regeneration and other fields of public policy (see Sullivan and Skelcher 2002, McQuaid 2010). However, whether that type of governance framework can be robust enough to prevent the dominance of group interests or the exclusion of less powerful stakeholders has been a contested issue (see Imrie and Thomas 1999, Deakin 2002).

As discussed earlier, so far the impacts of BIDs have not been to a scale that would substantially change the dynamics of their localities. BIDs have focused on marketing and safety, and have primarily made viable, expanded or enhanced activities and services already in place. Those interventions have been relatively uncontroversial, and have not diverted significantly from the 
agenda of place-making, local economic development and crime prevention pursued by local government. What the evidence suggests is that BIDs' business plans reflect aspirations for their area which are broadly in in line with those of the elected local authority and therefore, as far as it is possible to presume, with those of the majority of the electorate. There is scant evidence in England, so far at least, of systematic conflict between BIDs and non-business stakeholders (residents, town centre users, the homeless) of the kind recorded in the US (see Low 2006, Kohn 2004).

However, there is some evidence of potential tension within the BID between different sections of the business community (e.g. small x large businesses, independents $\mathrm{x}$ national chains, offices $\mathrm{x}$ retailers), replicating in a much more modest degree the North American experience (see Steel and Symes 2005). This is more palpable where the BID is perceived rightly or wrongly to be closer to particular groups of levy-payers than to others. Many potential conflicts of that nature have been dealt with preventatively, through a careful demarcation of the BID area. Nearly all of the cases have left outside their boundaries concentrations of resident population or of businesses to whom the BID is unlikely to appeal or for whose needs it could not cater, and who would be more likely to vote against it. Similarly, careful definition of exemptions or levy thresholds (e.g. Birmingham Retail does not charge levy from office users, Nottingham Leisure charges only licensed businesses, many BIDs do not charge the very small businesses) avoids tensions that would come from having to pay for services that might not be those businesses' first priority. Those who do not pay the levy do not vote in the BID or its decisions, but the assumption is that those businesses will benefit from many BID-funded services through the general improvement of the area. So far, the available evidence suggests this has held true.

Overall, therefore, the dual model of BID accountability - direct to levy-payers and indirect to the electorate as a whole through the supervisory role of the local authority - seems to have worked effectively. It has secured the accountability regime required for a direct connection between taxraising and spending, one of the most appealing characteristics of the BID as regards business 
investment in their localities. It seems also to have prevented tensions between BIDs' actions and the public interest embedded in public policy objectives. However, this might change, especially if there is an increase in the powers of BIDs or in the scope of their activities as suggested in the proposals for 'super BIDs' with more governance powers and responsibilities to lead the economic revitalisation of British town centres, formulated in a recent UK Government-commissioned report (Portas 2011). Similarly, a significant transfer of public services contracts to BIDs motivated by public spending cuts - already detected in the research - would also significantly alter the current balance. Accountability mechanisms might need to be rethought to find effective ways of giving a direct say in BIDs' decisions to a much wider range of stakeholders, well beyond levy-paying businesses.

\subsection{BIDs and spatially unequal provision of services?}

BIDs represent a differentiated pattern of service provision, determined by the willingness and ability to pay for a standard of services superior to that applying to surrounding neighbourhoods. However, as noted earlier, many urban regeneration policies in the UK have relied on area-based strategies that presuppose spatially differentiated public and private investment in places with a lagging economy or entrenched social problems, and their impacts are well documented (Bailey and Pill 2011, ODPM 2003, Rhodes et al. 2005). Voluntary Town Centre Management schemes are predicated on the same principle (Reeve 2008). The determinant of whether those policy-induced service inequalities are acceptable has been whether they help solve localised economic and social problem and therefore present a net gain for the towns and cities concerned. Indeed, concentrating private and public investment in services in town centres and business hubs as a way of maximising their potential contribution to the economic health of their wider location was at the heart of the justifications for introducing BIDs in the UK (DETR 2000, DTLR 2001). 
However, BIDs differ from area-based regeneration investment in three important aspects: their areas are self-selected and the limits defined by those with a direct interest in them; the amount of extra investment is directly related to local businesses' ability to pay; and the destination of the extra investment is determined by those paying for it (Briffault 1999). Consequently, regardless of their relative importance in citywide development strategies, richer locations with more affluent and better-organised businesses will therefore possess a clear advantage over poorer competing locations.

This raises the question of whether the differential service standards fostered by BIDs cancels out any distributive goals of citywide urban regeneration and economic development policies, with richer areas exploring their competitive edge over poorer ones with few overall gains.

At present, there is not enough data about the impact of English BIDs on the spatial dynamics of urban areas to provide a direct answer to that question. However, part of the answer is likely to come from the types, quality and quantity of services BIDs provide, which will determine the nature of the impact this localised extra provision might have in its area and more widely. Another part will come from the articulation of this spatially differentiated provision with normal patterns of service provision.

The previous section discussed how the services delivered by the ten case studies are largely the outcomes of longstanding agendas of urban regeneration and/or economic development programmes. Consequently, they are closely linked to wider strategies for the town/city shared with the local authority and implemented through a variety of programmes and actors. Therefore, the unequal provision of services enabled by BIDs is largely a part of the effort to achieve widely shared goals of regeneration/development.

The available evidence does not allow for significant insights into how BIDs can affect the relative competitiveness of locations within urban areas. However, it would be expected that areas with a BID would be at an advantage in relation those without one. The evidence of the cases does suggest 
that the ability of BIDs to provide enhanced services to their areas might make them more desirable as business locations. Three of the cases have expanded into adjacent areas when their mandate was renewed (London Bridge, Blackpool and Albion). This was mostly due to BID strategies to increase the levy base, but it also responded to the desire of businesses in adjoining areas, who did not want to lose out on the level of services provided by the BIDs. This was especially so in Industrial Area BIDs with regard to CCTV and policing services.

The literature also suggests that a sustained level of additional public realm services might in time lead to an increased differential in property values between BID and non-BID areas, with negative repercussions for smaller tenants and others (see e.g. Steel and Symes 2005, Hoyt and Gopal-Agge 2007). However, most BID areas are already prime areas for commercial real estate in their respective locations - all but the two industrial BIDs among the cases would fit in that description and therefore a rent-based differential already exists. Moreover, any increase in the commercial success of a town centre for whatever reason is bound to have the same effect. However, the relatively constrained portfolio of services and interventions suggested by the cases, even when successful in stimulating the economic vitality of their areas, is unlikely to generate in itself a noticeable impact on urban property values, except perhaps in the very long-term. Arguably, prestigious developments such as the 'Shard of Glass' within the London Bridge BID or the Bull Ring Shopping Centre within Birmingham Retail BID will have a bigger impact on rent and property value differentials than a minor increase in public realm services or a few extra marketing events.

Understanding the real impact of BIDs as providers of privately funded additional services requires far more information than currently available, and the limited evidence that exists does not allow for firm conclusions. However, the cases seem to corroborate the idea that UK BIDs have had only modest effect in reshaping the relative quality and economic competitiveness of urban locations. The areas that have created BIDs have been those that have been the more dynamic within their locations and therefore bound to attract more public and private investment with or without the 
coordination of a BID. In this sense, BIDs could be said to maintain a form of status-quo of relative competitiveness of urban areas. As to whether the enhanced service provision made possible by the BID and the levy can have negative impacts on other areas and on other stakeholders, the cases seem to confirm that the main issue might not be differentiated provision in itself, but instead how that provision is articulated with wider urban policy objectives and how the latter are set out.

\section{Conclusions}

This paper has looked at empirical evidence from the workings of 10 BIDs in England to elaborate on some of the main points of criticism to BIDs as urban governance bodies. These are their private governance character and potential threat to elected local government; their reduced accountability to citizens and other legitimate interests; their provision of services on an ability-to-pay basis and the potential inequalities that entails.

The particular legal and institutional settings in which BIDs exist and operate in the England warn against discussing BIDs in general, detached from the context in which their powers are defined and their room for action delineated. The paper adopts the premise that any investigation into the character of BIDs and their roles need to refer to their institutional context, and it is only with reference to it that they can be evaluated. Therefore, any theoretical or practical reflection on the limitations or the potential of BIDs should necessarily start from an understanding of their actual roles.

The evidence discussed in the paper corroborates the argument that BIDs in England are still a long way from constituting private government of commercial urban areas, akin to the managers of private shopping centres. They do represent commercial interests established in those areas, but in the context of a partnership with local government. Whereas the former has the power to raise a surtax and spend it on projects selected by their members, this happens within a framework of policies set out by the latter. Moreover, the nature of the services delivered by BIDs shows clearly 
that power and overall control over those areas are still in the hands of elected government, and that the transfer of governance responsibilities away from it has been relatively limited.

The evidence is less clear-cut about the accountability of BIDs and their alleged democratic deficit. English BIDs have a well-developed internal accountability system, which gives levy-payers decision over spending and the ability to terminate the BID should it not meet its objectives. This internal accountability is complemented by the role of the local authority in representing all the other more diffuse but legitimate interests on BID areas. The cases presented in this paper suggest that so far and for most BIDs this dual accountability system has manage to reconcile specific aspirations of levy-paying businesses with other interests as expressed in local authority policies and strategies. This might well be because the abilities of BIDs to effect structural changes in the way their localities are used is still limited, and many of the services they provide are either uncontroversial or indifferent to other actors with a stake in those localities. It can always be argued that confidence on the ability of local government to express effectively the concerns from all sectors of society is misplaced, and that local government itself suffers from a lack of democratic accountability, especially when elected with low turnouts (Goss 2001, Leach and Percy-Smith 2001). However, a lengthier discussion of this argument falls beyond the scope of this paper.

Finally, the paper comments on the unequal provision of services and its link to ability to pay that BIDs imply. English BIDs might be a policy import from North America, but they were inserted within a specific tradition of urban regeneration and urban economic development in which areabased interventions through partnerships of all sorts abound. Spatial differences in service provision are an integral part of those interventions, although in most case they are not so tightly bound to sectional interests, nor are they explicitly linked to ability to pay. However, for BIDs as for other area-based interventions, differential service provision is part of wider regeneration and economic development strategies led by local government, in which unequal provision is expected to create wider benefits. As mentioned earlier, there is enough evidence in the urban regeneration literature to 
suggest that this might not be always the case, but the negative impacts of BIDs should not differ much from that of other area-based interventions.

A last point is that the picture suggested here is not static. The paper describes and discusses how BIDs acted in their area governance roles in 2011 and 2012. The framework under which they operate and in which local authorities exert their coordinating role is in constant evolution, responding to pressures from changes in the economy and society. The current economic recession has challenged the viability of many retail-dominated town centres; current policies towards cuts in public spending have led local authorities to look for ways of transferring service provision to civil society. Proposals such as those in the report referred to earlier (Portas 2011), with an increase in the power and responsibilities of BIDs will certainly change their relative position and power in urban governance. In this eventuality, the questions posed by this paper should be revisited, and the forms found to manage cities, their commercial areas and their public realm reconsidered.

\section{References:}

ALG - Association of London Government, 2005, Local Authority Guide to Business Improvement Districts, London: ALG and London BIDs

Baer S and R Feiock, 2005, "Private governments in urban areas: Political contracting and collective action," American Review of Public Administration, Vol. 35 (1), pp 42-56

Bailey N and M Pill, 2011, "The continuing popularity of the neighbourhood and neighbourhood governance in the transition from the 'big state' to the 'big society' paradigm”, Environment and Planning C: Government and Policy, Vol. 29, pp 927-942

Blackwell M, 2005, “A consideration of the UK Government's proposals for business improvement districts in England: Issues and uncertainties”, Property Management, Vol. 23 (3), pp194-203 
Blackwell M, 2008, “Business Improvement Districts in England: The UK Government's Proposals, Enactment and Guidance”, in G Morçöl, L Hoyt, J Meek and U Zimmermann (eds.), Business Improvement Districts: Research, theories and controversies, Boca Raton: CRC Press, pp $451-472$

Briffault R, 1999, “A Government for our time? Business Improvement Districts and urban governance", Columbia Law Review, Vol.99 (2), pp 365-477

British BIDs, 2012, Nationwide BID Survey Report 2012, London: British BIDs

CLG - Department for Communities and Local Government, 2007, The Development and Implementation of Business Improvement Districts, London: CLG

CLG - Department for Communities and Local Government, 2010, Decentralisation and the Localism Bill: An Essential Guide, London: CLG

De Magalhães C and M Carmona, 2006, "Innovations in the management of public space: Reshaping and refocusing governance”, Planning Theory and Practice, Vol.7 (3), pp 289-303

De Magalhães C, 2012, "Business Improvement Districts and the recession: Implications for public realm governance and management in England”, Progress in Planning, Vol. 77, pp 143-177

Deakin N, 2002, "Public-Private Partnerships: A UK case study”, Public Management Review, Vol. $4(2), 133-147$

DETR - Department for the Environment, Transport and the Regions, 2000, Our Towns and Cities: The Future. Delivering an Urban Renaissance. The White Paper on Urban Policy, London: DETR DTLR - Department for Transport, Local Government and the Regions, 2001, Strong Local Leadership - Quality Public Services, London: HMSO

Foley P and S Martin, 2000, “A new deal for the community? Public participation in regeneration and local services delivery" Policy and Politics, Vol. 28, 479-491 
GCP \& GCDMA - Grand Central Partnership, Inc. and Grand Central District Management Association, Inc., 2010, Combined Financial Statements and Auditors' Report June 30, 2010 and 2009, New York: Skody \& Scot Co

Goss S, 2001, Making Local Governance Work: Networks, relationships and the management of change, Basingstoke: Palgrave

Hoyt L and D Gopal-Agge, 2007, “The Business Improvement District model: A balanced view of contemporary debates”, Geography Compass, Vol. 1 (4), pp 946-958

Imrie $\mathrm{R}$ and $\mathrm{H}$ Thomas (eds.), 1999, British Urban Policy: An Evaluation of the Urban Development Corporations, London: Sage

Justice J and R Goldsmith, 2006, "Private government or public policy tools? The law and public policy of New Jersey’s Special Improvement Districts”, International Journal of Public Administration, Vol.29, pp 107-136

Justice J and C Skelcher, 2009, “Analysing democracy in third-party government: Business Improvement Districts in the US and the UK”, International Journal of Urban and Regional Research, Vol.33 (3), pp 738-753

Kohn M, 2004, Brave New Neighbourhoods: The Privatisation of Public Spaces, London: Routledge

Leach R and J Percy-Smith, 2001, Local Governance in Britain, Basingstoke: Palgrave Lloyd G and D Peel, 2008, "From Town Centre Management to the BID Model in Britain: Toward a New Contractualism?”, in G Morçöl, L Hoyt, J Meek and U Zimmermann (eds.), Business Improvement Districts: Research, theories and controversies, Boca Raton: CRC Press, pp 71-94 Lloyd G, J McCarthy, S McGreal and J Berry, 2003, “Business Improvement Districts, Planning and Urban Regeneration”, International Planning Studies, Vol. 8 (4), pp 295-321 
Low S, 2006, "How private interests take over public space: Zoning, taxes and incorporation of gated communities", in S Low and N Smith (eds.), The Politics of Public Space, Abingdon: Routledge, pp 81-104

Low S and N Smith (eds.), 2006, The Politics of Public Space, Abingdon: Routledge

Madanipour A, 2003, Public and Private Spaces of the City, London: Routledge

Mallet W, 1994, “Managing the post-industrial city: Business Improvement Districts in the United States", Area, Vol.26 (3), pp 276-287

McQuaid R, 2010, “Theory of organisational partnerships: Partnership advantages, disadvantages and success factors, in S Osborne (ed.), The New Public Governance: Emerging Perspectives on the Theory and Practice of Public Governance, Abingdon: Routledge, pp 127-148

Minton A, 2009, Ground Control: Fear and Happiness in the Twenty-First-Century City, London: Penguin

Mitchell D and L Staeheli, 2006, "Clean and safe? Property redevelopment, public space and homelessness in Downtown San Diego", in S Low and N Smith (eds.), The Politics of Public Space, London: Routledge, pp 143-175

Morçöl G, L Hoyt, J Meek and U Zimmermann (eds.), 2008, Business Improvement Districts: Research, theories and controversies, Boca Raton: CRC Press

NWEC - New West End Company, 2008, Business Plan 2008-2013, London: New West End Company

ODPM - Office of the Deputy Prime Minister, 2003, Review of Area Based Initiatives, Impacts and Outcomes, London: ODPM

ODPM - Office of the Deputy Prime Minister, 2004a, Living Places: Caring for quality, London: RIBA Enterprises 
ODPM - Office of the Deputy Prime Minister, 2004b, Consultation Paper on Draft Business Improvement Districts (England) Regulations, London: ODPM

Peel D, G Lloyd and A Lord, 2009, "Business Improvement Districts and the discourse of contractualism”, European Planning Studies, Vol. 17 (3), pp 401-422

Portas M, 2011, The Portas Review: An independent review into the future of our high streets, London: Department for Business, Innovation and Skills

Reeve A, 2008, "British Town Centre Management: Setting the stage for the BID model in Europe”, in G Morçöl, L Hoyt, J Meek and U Zimmermann (eds.), Business Improvement Districts: Research, theories and controversies, Boca Raton: CRC Press, pp 423-450

Rhodes P, P Tyler and A Brennan, 2005, Assessing the effect of Area Based Initiatives on local area outcomes: Some thoughts based on the National Evaluation of the Single Regeneration Budget in England, Urban Studies, Vol. 42 (11), 1919-1946.

Rhodes R, 1997, Understanding Governance: Policy Networks, Governance, Reflexivity and Accountability, Buckingham: Open University Press

RICS - The Royal Institution of Chartered Surveyors, 2011, BIDs, Economic Recession and the Future of Stakeholder-led Public Realm Management, London: RICS Research

Schaller S and G Modan, 2009, “Contesting public space and citizenship: Implications for Neighbourhood Business Improvement Districts", Journal of Planning Education and Research, Vol. 24, pp 394-407

Steel M and M Symes, 2005, “The privatisation of public space? The American experience of Business Improvement Districts and their relationship to local governance”, Local Governance Studies, Vol. 31 (3), pp 321-334

Sullivan H and C Skelcher, 2002, Working Across Boundaries: Collaboration in Public Services, Basingstoke: Palgrave 
TSDMA - Times Square District Management Association, Inc., 2010, Financial Statements and Auditors' Report June 30,2010 and 2009, New York: Skody \& Scot Co

UK Parliament, 2004, Statutory Instrument 2004 No. 2443 - The Business Improvement Districts (England) Regulations 2004, London: HMSO

Urban Task Force, 1999, Towards an Urban Renaissance, London: E \& FN Spon

Vindevogel F, 2005, "Private security and urban crime mitigation: a bid for BIDs", Criminal Justice, Vol.5 (3), pp 233-255

Ward K, 2006, "Policies in motion: Urban management and state restructuring: The trans-local expansion of Business Improvement Districts", International Journal of Urban and Regional Research, Vol. 30 (1), pp 54-75 